\title{
The Ecological Crisis and Indonesian Muslim Organizations' Responses
}

\author{
Indria Hartika Rukmana \\ Center for Religious and Cross Cultural Studies, Universitas Gadjah Mada, Yogyakarta \\ <indriahartika@mail.ugm.ac.id>
}

\begin{abstract}
This paper focuses on Muslim initiatives on saving the environment. It examines various attempts, commitments, statements, and declarations by Muslims around the world to see how these have affected two mass Muslim organizations in Indonesia, namely Nahdhatul Ulama and Muhammadiyyah. This paper describes initiatives that have been proposed by international and national Muslim organizations on the environment and analyzes how these initiatives have been implemented by Nahdhatul Ulama and Muhammadiyah organizations in Indonesia based on their two publications about plastic waste. In addition, this paper explores various initiatives in the world that commit to protect nature, carried out in numerous ways ranging from theological to practical. In particular the efforts to overcome plastic waste in An-Nur mosque in Bantul by reducing the use of plastic waste in several mosque events as well as conducting training on organic and non-organic waste sorting. In addition, practical paths are carried out by several environmental activists in Yogyakarta who make several environmentally friendly products and trash banks as an alternative to advocating for waste. Various commitments were built to lead to a clean environment free of garbage. It is important to see aspects of the faith that play a strong role in the awareness of the importance of protecting the earth in the future.
\end{abstract}

Keywords: Muslim organization, initiatives, environmental activists, Yogyakarta

\section{Introduction}

Religion holds the potential to overcome the environmental crisis. In Indonesia, Majelis Ulama Indonesia (MUI) has issued two statements, which confirm that Muslims should protect the environment. First, statement number 4/2015 concerning the preservation of endangered species to maintain ecosystem balance. Second, statement number 41/2014 concerning waste management to prevent environmental damage. In addition, in the context of 
the 29th NU Muktamar in February 2019 , one of the issues discussed was a boycott of companies that did not manage waste well and the threat of plastic waste for environmental damage. [4] The Muktamar urged Muslim leaders to participate in answering the challenges of the destruction of the environment through the basis of the scriptural proposition.[4]

Parallel to this, the Nadhatul Ulama (NU) published a book titled Fiqih Sampah Plastik aimed at contributing to the prevention of waste with Islamic theology. The importance of religion's role in tackling plastic waste is argued as an effort to preserve nature as a creation of Allah SWT. The book outlines verses in the Koran that correlate with environmental damage and how Muslims must guard it. In addition, there are strategic steps taken by Nadhatul Ulama (NU) in efforts to tackle plastic waste including waste management using the garbage bank systems and waste management with ecobricks. This book illustrates that theological doctrine towards practicality in facing the challenges of the ecological crisis becomes the challenge of religious communities.[7]

The overflowing waste discharge that occurred at Piyungan TPST (Tempat Pembuangan Sampah Terpadu or integrated landfills) Yogyakarta in December 2018 and March 2019 shows that the level of trash production in Yogyakarta is very high. The data collected at Piyungan TPST shows there is as much as 580 tons of garbage entering every day.[11] Even though some places in Yogyakarta regency already have a trash bank facility, public awareness to put trash in the trash bank is still not comprehensive. However, the fantastic amount of overflowing rubbish shows the lack of human awareness in household waste disposal. This is in line with my experience as a founder of the Nandur Uwuh trash bank in Bantul, which finds several problems every week related to the lack of human awareness to have the willingness to sort trash that is decomposed or unraveled. This results in the fact that unsorted waste will enter Piyungan TPST, where the amount of waste deposits is increasing every day. The crisis of waste collection and access to management is one factor that does not touch the community. This makes the waste management system in Yogyakarta still experiencing a growing crisis.

From the above explanation, it is clear that religion could play an important role in rebuilding and preserving the environment. The proposed research analyzes to what extent these initiatives have been implemented by one of the mass Muslim organizations. Several environmental movements make religion as a moral treasurer supporting always be responsible for the preservation of nature. 


\section{Initiative of Muslim Communities}

Environmental Campaign on Social Media

A search on social media found four Muslim communities in the world who have the initiative in carrying out environmental campaigns. The four communities are the Global Muslim Climate Network (@muslimclimate), Green Muslim (@green_muslims), Ecomasjid, and khaleafa.com. Based on the community on social media have statements, declarations, and their actions in protecting nature. Below we will describe the four community findings in the social media.

The Global Muslim Climate Network is an international Muslim community that has the vision to deal with environmental problems. The forms of community action are campaigning on social media to become environmentally friendly Muslims. As in one of the posts on Instagram, "five simple steps to creating a Green Ramadan: Conserve food during iftars and avoid being wasted by giving excess food to people in need, use relatively quick degradable paper products for iftars to avoid the use of styrofoam cups and plates, recycle material, especially plastic water bottles, replace all light bulbs with energy saver bulbs and the converse electricity, give a sermon on the Islamic imperative to conserve and protect the environment."Organisasi ini mendeklarasikan muatan kampanye lingkungan hidup bagi orang Muslim di dunia."[12] Ecomasjid is a community based in the mosque that cares about the environment. This movement originated from Indonesia which carried campaign programs to the mosque to make the mosque more environmentally friendly. One form of action in this community campaign is the use besek (bamboo cubes) for the distribution of sacrificial meat during Eid al-Adha at the Istiqlal Mosque in Jakarta, which in the previous year used plastic. [13] In addition, environmental-based campaigns are also in the form of religious lectures with the theme of a clean and healthy environment. In collaboration with the MUI (Majelis Ulama Indonesia), the Ecomasjid conducts training to help make Muslims more responsible with their rubbish, for example, getting used to carrying old newspapers and throwing them into the trash after the Eid al-Fitr prayer and appeals to process sacrificial animal waste to be used as fertilizer or buried in the ground. These community actions show that mosque-based environmental awareness is also important because environmental damage is also present in mosque activities.[13]

Green Muslims is a movement that centred on the Muslim community that moves in the environment around the world.There are several declarations and statements about the forms of environmental campaigns by Muslims around the world. One of the goals of 
this organization is to build a Muslim world view that cares about nature and reflects on the environment on a spiritual basis. This organization also launched an Environmental campaign program by opening an Islamic value-added program based on the environment. This program is called "Interfaith Learning and Activism: Exploring Why Nature Is Important for Us". This program is for children around the world aged 8 to 13 years from all religious backgrounds to conduct interfaith dialogue and to save nature together.[14]

Khaleafa.com is the website of Muaz Nazir, a Muslim activist from Canada who conducts environmental campaigns on social media. He conducted his campaign that is the "Green Sermon Campaign" with writings for a Muslim to live an environmentally friendly lifestyle. From this website there are several alternatives for a Muslim to be able to live an environmentally friendly lifestyle. Some articles about Muslims always living environmentally friendly at home, office, travel compilation, and joining an environment-based organization. One of the statements on this website is: "Small changes around the house and on the lawn can reduce your carbon footprint and save money, businesses use large amounts of energy for heating, cooling, lighting, and using equipment. There are several simple ways to reduce energy use, and going to and from home, school or office can be done more intelligently by following a few simple steps.'[15]

Based on this website, visitors can find various lifestyle alternatives for Muslims who cares about the environment. The contents of the writings which show that a Muslim must care about the environment becomes one thing that shows that environmental problems must be dealt with quickly through the help of religious people.

The explanations above describe some initiations of Muslim organizations in the world that carry out environmental campaigns. Within the context of Indonesia, the two large Muslim organizations, namely Nadhatul Ulama (NU) and Muhammadiyah, through two publications have developed initiatives to solve environmental issues especially related to waste management. The two publications are the Plastic Waste Fiqh book by NU and the 2014 MUI Fatwa by Muhammadiyah. Both of these books explain that Muslims must always care for the environment by being created by God.

\section{Indonesian Muslim Organizations '}

\section{Responses}

Fiqh Sampah Plastik by NU is a book created to address the attitude of the public who ignore plastic waste. This book gives an illustration that NU has efforts in managing plastic waste by 
carrying out various waste management efforts. One potential strategy is to open up waste management through a garbage bank, ecobrick, and the "Nusantara Free Garbage" campaign. At the praxis level, the raising of the Nusantara issues free of rubbish is continued with direct assistance work in the community, especially in the boarding school environment which is under the auspices of the NU jam 'iyah. Conducting a roadshow program to several points of visit in the area.[7]

The program launched by NU in the book contained the active participation of the NU community in the management of plastic waste. In practice this assistance is in several pesantren of NU in Indonesia. In addition, the Director of the Nusantara Garbage Bank (BSN) and the Nahdlatul Ulama Disaster Management and Climate Change Institute (LPBINU) were present at the event initiated by the Directorate of Environmental Partnerships at D'Khayangan Senior Living Jababeka, Bekasi, West Java Ministry of Environment and Forestry (KLHK). This is in the context of encouraging community participation in environmental protection and management activities because in the Bekasi area garbage collection is no longer receiving waste due to overloads. [6]

In another case, in a statement by the MUI in 2014 established a fatwa on waste management to prevent environmental damage. Some of the decisions in the fatwa related to the law are:

1. Every Muslim is obliged to maintain the cleanliness of the environment, to use goods for the benefit of benefit and to avoid themselves from various diseases and acts of tabdzir and israf.

2. Disposing of littering and / or disposing of goods that can still be used for self or others' sake is forbidden.

3. Governments and Entrepreneurs must manage waste to avoid harm to living things.

4. Recycling waste into goods that are useful for improving the welfare of its people must be kifayah.[5]

In addition, the role of religious leaders is also required to contribute to this fatwa, namely:

1. Give religious understanding about the importance of preventing environmental damage and maintaining ecosystem balance through good waste management;

2. Conducting socialization, playing an active role, and making people aware of waste management and responsible life attitudes through a religious approach;

3. Encourage the preparation of religious guidelines and the formation of "Dai Environment" in order to realize public awareness in waste management.[5]

Mosque Event: Reducing Plastic Waste The initiatives to protect nature 
are carried out from theological to practical. One example on a local scale is the the efforts to overcome plastic waste in An-Nur mosque in Bantul, through training on organic and nonorganic waste sorting to reducing plastic waste. The training program expects to make people aware and taken action to reducing plastic. This program is one implementation of the Muslim organization initiative that practices in Bantul, Yogyakarta.[16]

The training program collaborates with Nandur Uwuh trash bank to maintain the garbage in the Mosque until now. This collaboration between local trash bank and Mosque show that religious activity can contribute to protecting nature. In addition, the collaboration can use as an alternative to advocating for waste. Various commitments were built to lead to a clean environment free of garbage.[16]

From the above explanation, the findings of this data are then analyzed using one of the theories from Fachrudin Mangunjaya which explains about the four pillars as a solution to solving natural ecological structuring.

\section{Analysis}

The book of Fiqh published by NU highlights practical steps taken by NU institutions in tackling the current plastic waste problem. Theological doctrine is not thoroughly covered in the book but rather the efforts made are more practical. This is in line with the statement of Fachruddin Mangunwijaya who returned the task of humans as the manager of nature (khalifah) on earth. The steps which are based on theological roots go to the practical dimension, reflecting the efforts made by NU to face the challenges of the ecological crisis. It is hoped that these efforts will work together with several $\mathrm{NU}$ affiliates in the archipelago to jointly face environmental problems.

The MUI fatwa by Muhammadiyah shows the limiting role for human bad behavior in damaging existing ecosystems on earth. This fatwa became a tool used by Muhammadiyah to proclaim that Muslims must work together to deal with plastic waste. The importance of the role of religious leaders is also in this fatwa so that in the practice of preaching can spread propaganda that is environmentally friendly to other Muslims.

This fatwa was made in 2014. Until now, several movements in waste management have not been widely spread, especially in Yogyakarta, the majority of which are Muhammadiyah. Some Muhammadiyah mosques in Yogyakarta as far as I know in Bantul have not fully played a role in waste waste treatment. And in some practices they still use plastic as their packaging.

The trash free movement is more effectively and practically followed without the affiliation of religious organizations. This is because the problem of garbage is a universal 
human problem. Some religious organizations are more inclined in strengthening the values of spirituality that pivots on the human dimension. Therefore, in the outer dimension of the faith is often ignored.

My experience in working with a Muhammadiyah mosque, in Bantul, Yogyakarta to conduct organic and nonorganic waste sorting training still faces obstacles. One of them is, the 2014 MUI fatwa which still sounded foreign and did not spread widely throughout the archipelago. The result is that practical waste management in Muhammadiyah is still hampered. However, when entering into the leadership of the mosque and explaining the purpose of this training for the mutual benefit of those who live in the local environment, the implementation will proceed. The MUI fatwa was not yet strong enough to encourage Muslims to conduct waste management training.

Two publications of NU and Muhammadiyah are a form of ecological crisis response that brings theology into the discourse of environmental problems. This initiative is influenced by several statements, declarations and actions from world organizations that contribute to addressing global environmental issues. The influence is in some of the above publications in the framework of the background book of Plastic Waste Fiqh by NU which states that the issue of the global environmental crisis must be immediately addressed together.

The influence of the global Muslim organization focused on the environment becomes a reference for the responses of two large Muslim organizations in Indonesia in facing the challenges of religious communities in the environmental crisis. However, this certainly experiences several obstacles in its implementation in society. The fact that is said by Fachruddin Mangunwijaya that explains the four pillars in the religion of Islam that are the solution to environmental problems is in the level of theological dogma of religion. The important issue that needs to be strengthened in the discourse of Muslim organizations is in religious doctrine which involves the role of religious leaders to jointly invite their followers to carry out waste management.

Author argue that the strategic step in the effort to manage plastic waste is by inviting religious scholars or leaders of religious organizations to build concrete steps in waste management. This can be done by holding waste management training in each mosque to be the first step to make Muslims aware that the importance of managing plastic waste. Using tools in religious events that are environmentally friendly can also be used as a strategy to increase human awareness in the importance of waste management.

The above is aimed at opening the space for greater consideration for 
religious leaders in how to respond to the challenges of the ecological crisis. The scientific discourse that is not narrow allows religious leaders to open themselves to receive knowledge related to the importance of waste management which is an urgency nowadays.

\section{Conclusion}

The implementation of two publications by two mass Muslim organizations in Indonesia, namely Nadhatul Ulama and Muhammadiyah, cannot be fully applied in Indonesia. The problem of plastic waste is a complex problem. The challenge of the two organizations is to include ecological contents in theological doctrines and activities. Strengthening of the two organizations can be done if there are efforts of the religious leaders of each organization to jointly invite Muslims to participate in every waste management activity.

\section{Acknowledgement:}

The research for this paper was supervised by Michael Northcott. In addition, author thanks to Sekolah Pascasarjana UGM for supporting the research.[]

\section{References}

[1] J. L. Bower, and C. M. Christensen. "Disruptive Technologies: Catching the Wave."

[2] Sayyed Hosein Nasr, Man and Nature: The Spritual Crisis of Modern Man. London: Alen and Unwin, 1967.

[3] Interfaith Rainforest Initiative, last modified 10th 2019, https://www.interfaithrainforest. org/about-us

[4] NU Mukhtamar in Pesantren Miftahul Huda Al-Azhar Citangkolo Kujangsari, Langensari, Banjar City, West Java, on 27 Februari-1 Maret 2019, last modified 11 June 2019,https:// www.pikiran-rakyat.com/nasional/2019/01/31/isu-sampah-plastik-akan-dibahas-dimunas-nu-februari-2019.

[5] MUI Statements number 4th 2014, last modified 11 June 2019, http://acehinsight. com/2015/11/05/pdf-fatwa-mui-no-4-tahun-2014-tentang-pelestarian-satwa-langkauntuk-menjaga-keseimbangan-ekosistem/ and MUI statement number 41 2014, last modified 11 June 2019, https://mui.or.id/tag/sampah/.

[6] Ibnu Nawawi, NU Online, https://www.nu.or.id/post/read/104126/bank-sampahnusantara-beri-pelatihan-pengolahan-sampah-mandiri

[7] Said Agil Siro. Fiqih Sampah Platik. LPBI PBNU and Lembaga Bahtsul Masail PBNU: Jakarta. 2019, pp.18.

[8] Muaz Nazir, “About the Publisher and Editor”, in Khaleafa website, http://www.khaleafa. com/who-we-are

[9] Green Muslim Summer, "Interfaith Learning and Activism: Exploring Why Nature Matters to Us", https://www.greenmuslims.org/summer

[10] Fachruddin Mangunwijaya. Konservasi Alam dalam Islam. Jakarta: Yayasan Obor Indonesia. 2015.

[11] Irwan Syambudi, "Dibalik Protes Warga yang Berujung Akses TPST Piyungan 
Ditutup",https://tirto.id/di-balik-protes-warga-yang-berujung-penutupan-akses-tpstpiyungan-dkoR. 2019.

[12] Global Muslim Climate Network, Access on Instagram account: https://instagram.com/ muslimclimate?igshid=11mu64f6uen 15

[13] Ecomasjid.id, Acess on Instagram account:https://instagram.com/ecomasjid. id?igshid=sdhcu4gmztuq

[14] Green Muslims, Access on Instagram account:https://instagram.com/ecomasjid. id?igshid=sdhcu4gmztuq

[15] Khaleafa: A Sacred Trust, website: http://www.khaleafa.com/

[16] Action Research in the An-Nur Mosque in Bantul Yogyakarta: 10 Octobet 2019. 